Research Article

\title{
Effectiveness of Selected Cold Chain Management Practices to Extend Shelf Life of Mango Fruit
}

\author{
Emmanuel M. Amwoka, ${ }^{1}$ Jane L. Ambuko $\mathbb{D},{ }^{1}$ Hutchinson M. Jesang', ${ }^{1}$ and Willis O. Owino ${ }^{2}$ \\ ${ }^{1}$ Department of Plant Science and Crop Protection, University of Nairobi, P.O. Box 29053-00625, Kangemi, Nairobi, Kenya \\ ${ }^{2}$ Department of Food Science and Technology, Jomo Kenyatta University of Agriculture \& Technology, P.O. Box 62000-00200, \\ Nairobi, Kenya
}

Correspondence should be addressed to Jane L. Ambuko; ambuko@yahoo.com

Received 12 September 2020; Accepted 31 May 2021; Published 8 June 2021

Academic Editor: Jiban Shrestha

Copyright $\odot 2021$ Emmanuel M. Amwoka et al. This is an open access article distributed under the Creative Commons Attribution License, which permits unrestricted use, distribution, and reproduction in any medium, provided the original work is properly cited.

\begin{abstract}
An on-farm study was conducted among smallholder mango farmers in Embu County of Kenya to demonstrate the effectiveness of simple harvest and postharvest handling practices to attain cold chain and extend mango shelf life. The recommended cold chain practices were compared with common farmers' practices. 'Apple', 'Ngowe', 'Kent', and 'Tommy Atkins' harvested at the mature green stage were used in the study. To demonstrate proper cold chain, fruits were harvested before 8 am, transported in crates lined with dampened newspapers, precooled in an evaporative charcoal cooler, and then transferred to a Coolbot ${ }^{\mathrm{TM}}$ cold room $\left(10 \pm 2^{\circ} \mathrm{C}\right)$. To demonstrate common farmers' practices, fruits were harvested at noon, transported in open crates, and stored at ambient room conditions $\left(25 \pm 7^{\circ} \mathrm{C}, 55 \pm 15 \% \mathrm{RH}\right)$. The air and fruit pulp temperatures were monitored regularly using HUATO $^{\circledast}$ data loggers. During the storage period, a random sample of 3 fruits (per variety) per treatment was taken after every 3 days to evaluate ripening related changes including physiological weight loss, colour, firmness, and total soluble solids. Proper cold chain practices resulted in low fruit pulp temperature (average $11^{\circ} \mathrm{C}$ ) compared to $25^{\circ} \mathrm{C}$ for fruits handled using common practices by farmers leading to faster ripening as evidenced by lower peel/pulp colour and firmness, higher physiological weight loss, and higher total soluble solids. For example, flesh firmness of fruits under poor cold chain practices decreased from initial $36.6 \mathrm{~N}, 45.9 \mathrm{~N}, 66.5 \mathrm{~N}$, and $46.8 \mathrm{~N}$ to $3.1 \mathrm{~N}, 2.4 \mathrm{~N}, 3.2 \mathrm{~N}$, and $3.1 \mathrm{~N}$ for 'Apple', 'Ngowe', 'Kent', and 'Tommy Atkins' varieties, respectively, at the end of storage while that of fruits under proper cold chain practices reduced to $2.3 \mathrm{~N}, 1.5 \mathrm{~N}, 3.9 \mathrm{~N}$, and $2.9 \mathrm{~N}$, respectively, for the four varieties at the end of storage. Overall, proper cold chain management extended mango shelf life by 18 days. Application of simple harvest and handling practices coupled with simple storage technologies can attain and maintain the cold chain required to preserve quality and extend shelf life. This could increase the marketing and storage periods for later selling and processing, respectively, of mango fruits.
\end{abstract}

\section{Introduction}

Mango (Mangifera indica L.) is one of the main fruits produced in Kenya mainly for the domestic market and to a small extent for export. It is ranked 2nd in both value and export market after banana and avocado, respectively [1]. Mango production has increased over the past years as evidenced by the area under production increasing by 1,452 ha from 2016 to 2017, a 3\% rise. This increase can be attributed to increased demand for fresh market, fruit processing, and health concerns among the consumers [1].
However, despite the increase in production and mango's growing economic importance in recent years, its value has not been fully exploited due to various factors, including high postharvest harvest losses along the mango value chain. It is reported that at least $40-45 \%$ of the mango fruits are lost due to poor handling of harvest and postharvest handling practices [2].

Mango is a highly perishable fruit with a short shelf life after harvest. Ripening and subsequent deterioration of the fruit are attributed to various physiological processes, including respiration, softening, and colour changes. The rate 
of ripening and deterioration of the fruit due to these physiological processes is affected by environmental factors including temperature and relative humidity [3]. In handling perishable commodities such as fruits and vegetables, maintenance of low but safe temperatures during handling of the produce from harvest to the end-user (cold chain) is critical for preserving the quality. Cold chain for perishable products is the continuous handling of the produce in cool temperatures during postharvest handling from harvest, collection, transport, storage, processing, and marketing until they reach the final consumers [4]. Components of a proper cold chain are divided into seven, namely, on-farm cooling, initial cooling, storage, transportation, distribution, retail, and consumer, with possible temperature management. An increase in temperature by $10^{\circ} \mathrm{C}$ above optimum increases the deterioration rate in perishable commodities 2 3 -fold. Delays between harvesting and cooling or processing can result in quantitative losses (due to water loss and decay) and qualitative losses (losses in flavor and nutritional quality) [5]. Proper cold chain management reduces respiration thus lessens perishability, reduces transpiration and hence lessens water loss and shriveling, reduces ethylene production and increases resistance to ethylene action slowing ripening and natural senescence, decreases the activity of microorganisms, and reduces browning and loss of texture, flavor, and nutrients [4]. Cold chains have been used to maintain postharvest quality of fruits during shipment, marketing, and storage before consumption.

Besides temperature, relative humidity is another environmental factor contributing to the deterioration of harvested perishable produce such as fruits and vegetables. Physiological water loss that results in shriveling contributes significantly to the production of deterioration and postharvest losses in perishable commodities. At harvest, the harvested crop may lose water due to several factors including harvest maturity, environmental conditions and harvest techniques, and physical injury [6]. Harvesting fruits during hot times of the day will result in high heat load in harvested produce, leading to high respiration and transpiration and hence increased water loss during prolonged storage [7]. This is due to increased vapour pressure deficit within the produce tissue that may cause fruit cracking and hence peel permeance allowing increased water loss after harvest. Physiological water loss is further aggravated by poor postharvest handling practices [6]. Low temperature and high relative humidity are key in reducing water loss from the fruit to the surroundings, suppress enzymatic and respiratory activities leading to ripening and senescence, and slow pathological activities creating a safe environment for fruit preservation. On the contrary, high temperatures and low relative humidity at harvest time result in water loss causing fruits to shrivel, lowering quality [8].

Most farmers perceive cold chain management as a complex system that requires high-cost infrastructure including conventional cold rooms and refrigerated transport. However, smallholder farmers can achieve the same benefits of the conventional cold chain management practices by applying simple harvest and postharvest handling practices coupled with low-cost storage technologies.
Harvesting produce during cooler times of the day reduces heat load which would otherwise result from high temperatures and exposure to direct sunlight during hotter times of the day [9]. Harvesting early in the morning when plant cells are turgid minimizes water loss and significantly enhances shelf life and preserves quality. Studies in French beans showed that harvesting during hotter hours lost significantly higher water during storage [10]. Immediately after harvest, the use of field shades to keep the produce cool also reduces the amount of heat load in the produce. Field shades cool produce, thus decreasing metabolic reactions in harvested produce [11]. Harvested produce should be transported from the field to storage immediately. Delays in the field may expose the produce to more heat and hence high heat load in harvested crops, affecting shelf life and quality [10]. For produce destined for cold storage, the longer the duration to cooling, the longer the time to attainment of set storage temperature. Past studies show that a delay by one hour between harvest and precooling causes a loss of one day in the shelf life [12]. Precooling before cold storage is necessary to remove field heat in harvested produce [4]. Removal of field heat by precooling reduces postharvest decay, controls the development of physiological disorders, and decreases metabolic activities such as respiration rate and ethylene production, thus delaying ripening, ageing, and senescence [13]. 25-30\% postharvest losses are recorded in unprecooled commercial fruits and vegetables while only $5-10 \%$ postharvest losses are recorded for precooled produce [14]. Precooling coupled with other cool chain practices and technologies has been used to extend shelf life and preserve the quality of harvested tomatoes [15].

Cold storage in perishable produce can be achieved through the application of low-cost cold storage technologies. Examples of low-cost technologies that have been used successfully to preserve the quality of perishable produce include the Coolbot ${ }^{\mathrm{TM}}$ cold room, solar-powered coolers, and evaporative cooling technologies. The Coolbot ${ }^{\mathrm{TM}}$ cold room is a low-cost cold storage alternative to conventional cold rooms. The Coolbot ${ }^{\mathrm{TM}}$ cold room is composed of the Coolbot $^{\mathrm{TM}}$, a compatible air conditioner (AC) and an insulated room. The Coolbot ${ }^{\mathrm{TM}}$ is an electronic gadget that overrides the thermostat of the AC, thereby enabling it to cool the room to lower than set temperatures (usually $18^{\circ} \mathrm{C}$ ) without ice buildup on the evaporator coils [16]. Coolbot ${ }^{\mathrm{TM}}$ cold room has been utilized to extend mango's shelf life [17] and other produce such as turnips, potatoes, tomatoes, and beans. The Coolbot ${ }^{\mathrm{TM}}$ cold room's advantage over conventional cold rooms is that it is relatively affordable (compared to the conventional cold room), electricity-efficient, and environmentally friendly [16]. For the off-grid smallholder farmers, evaporative cooling provides a feasible alternative. Evaporative coolers work on the principle of evaporative cooling whereby when water held in a wetted medium (charcoal or sand) evaporates, it draws heat from the surroundings, creating a cooling effect [18]. Evaporative coolers are considered feasible and appropriate for smallholder rural farmers because they can be made from locally available materials and the costs of running them are low. However, the cooling achieved by evaporative coolers is 
dependent on the surrounding environment, temperature, and relative humidity and the cooling attained is often not low enough to slow down some of the deteriorative processes [19]. Evaporative cooling is effective for precooling and short-term storage of harvested produce. Different evaporative coolers have been used to extend shelf life and preserve the postharvest quality of horticultural crops such as leafy vegetables [19] and tomato [20].

Application of cold storage technologies can extend the marketing period of perishable produce such as mango, thereby avoiding distress sales by smallholder farmers who are otherwise vulnerable to middlemen. This study's objective was to evaluate the effectiveness of selected cold chain management practices and technologies to achieve effective cooling and extend the shelf life of mango fruit.

\section{Materials and Methods}

2.1. Study Site. The study was conducted in Karurumo area (S $0^{\circ} 28^{\prime} 11.6184^{\prime \prime}$ E $\left.37^{\circ} 39^{\prime} 47.466^{\prime \prime}\right)$, Runyenjes subcounty, Embu County in Kenya. Embu County is located in a medium potential region, agroecological zone (AEZ) III. It receives a total annual rainfall of averagely $1067.5 \mathrm{~mm}$ (received twice in a year) at an altitude of $700 \mathrm{~m}-6500 \mathrm{~m}$ above sea level, and the temperatures range from $26^{\circ} \mathrm{C}$ to $35^{\circ} \mathrm{C}$.

2.2. Experimental Design. Uniform mature green mango fruits of 'Apple', 'Ngowe', 'Kent', and 'Tommy Atkins' varieties were harvested at two different times of the day from 3 selected farms. To demonstrate proper cold chain practices, all the four mango varieties were harvested in the morning (before $8 \mathrm{am}$ ) and transported to the experimental site in crates lined with dampened newspapers to simulate evaporative cooling during transit. Upon arrival at the aggregation centre, fruits were sorted for uniformity based on size and freedom from damage. They were then precooled in an evaporative charcoal cooler until temperatures stabilized at $22.2^{\circ} \mathrm{C}, 22.03^{\circ} \mathrm{C}, 22.1^{\circ} \mathrm{C}$, and $22.07^{\circ} \mathrm{C}$ for 'Apple', 'Ngowe', 'Kent', and 'Tommy Atkins' varieties, respectively, and then stored in the Coolbot $\left.{ }^{\mathrm{TM}}(12 \pm 2)^{\circ} \mathrm{C}\right)$ in open crates. In the second harvest, in order to demonstrate farmers' practices, fruits of the same varieties were harvested the same day at midday (noon) and transported to the experimental site in open crates. At the centre, the fruits were sorted for uniformity and stored directly under ambient conditions $\left(25 \pm 7^{\circ} \mathrm{C}\right)$, with relative humidity of $55 \pm 15 \%$. The experiment was laid down as a completely randomized design (CRD) with a factorial treatment arrangement. Factor 1 was cold chain practices with two levels: cold chain (Treatment 1) and no cold chain (Treatment 2). Factor 2 was variety with 4 levels: 'Apple', 'Ngowe', 'Kent', and 'Tommy Atkins'. The treatments were replicated three times.

\subsection{Data Collection}

2.3.1. Air Temperature and Air Relative Humidity (\%). The air temperature and percentage relative humidity inside the Coolbot ${ }^{\mathrm{TM}}$ cold room and ambient room were regularly monitored using HUATO ${ }^{\circledR}$ data loggers (Model HE17x, Huato Electric Co., Ltd., Shenzhen, China) after every one hour. The loggers' data were retrieved at the end of the experiment by downloading recorded data using HUATO ${ }^{\oplus}$ app.

2.3.2. Pulp Temperature. The pulp temperature of the fruits was recorded at harvest time, upon arrival at the centre, after every one hour for precooled fruits till temperatures stabilized, and then after every three days in both treatments. This was done by plunging the temperature probes' tip into the 3 sample fruits and measurement on the probe taken. The 3 measurements were averaged and presented as the internal pulp temperature.

2.3.3. Percentage Cumulative Weight Loss. In each treatment, three fruits per variety numbered 1 to 3 were used to measure cumulative weight loss using a digital weighing scale (Model Libror AEG-220, Shimadzu Corp., Kyoto, Japan). The mango fruits' initial weight at day 0 after harvest was recorded; then the new weight of the same fruit on each sampling day was noted. Data were collected every 3 days in both treatments. Percentage cumulative weight loss was calculated using

$$
\text { cumulative weight loss } \%=\frac{(w 1-w 2)}{w 1} \times 100 .
$$

2.3.4. Peel and Flesh Colour. Peel and flesh colour were determined by sampling three fruits per treatment and measuring two different spots along the equator using a Minolta colour meter (Model CR-200, Osaka, Japan), calibrated with a standard white piece of paper. To access the flesh, the three sampled fruits were cut open longitudinally and measurements were taken at two different spots. Data were collected every 3 days in both treatments. Colour coordinates $\left(L^{*}, a^{*}\right.$, and $\left.b^{*}\right)$ were obtained and then hue angles $\left(h^{\circ}\right)$ were calculated by converting $a^{*}$ and $b^{*}$ as shown in

$$
\text { Hue angle }(H o)=\arctan \left(\frac{b}{a}\right), \quad \text { for }+a \text { and }+b \text { values. }
$$

2.3.5. Peel and Flesh Firmness. Three fruits per treatment were sampled and peel and flesh firmness were measured at two different, intact, and peeled mango spots using a penetrometer (Model CR-100D, Sun Scientific Co., Ltd., Japan) fitted with a $5 \mathrm{~mm}$ probe. For the flesh firmness, the probe was allowed to penetrate to a depth of $1.5 \mathrm{~mm}$ and the corresponding force required to penetrate this depth was determined. Data were collected every 3 days in both treatments. Firmness was expressed as Newton (N).

2.3.6. Total Soluble Solids (TSS). Three fruits per treatment were sampled and total soluble solids were determined using an Atago hand refractometer (Model 500, Atago, Tokyo, 
Japan). On each sampling time, $3 \mathrm{ml}$ of the fruit juice was extracted from three different fruits by pressing and placed on the hand refractometer to obtain the Brix level. Data were collected every 3 days in both treatments. The total soluble solid was then expressed as oBrix.

2.3.7. Overall Shelf Life. The mango fruits' total shelf life was determined by counting the number of days taken to reach the end-stage. End-stage was based on firmness and visual appearance at which the fruit was saleable.

2.4. Data Analysis. The data collected was analyzed using the GenStat $15^{\text {th }}$ Edition statistical program. Analysis of variance (ANOVA) was used to test for significant differences among treatments for each parameter and means separated using Fischer's protected least significant difference at $P=0.05$.

\section{Results}

3.1. Changes in Air Temperature and Percentage Relative Humidity in the Coolbot ${ }^{\mathrm{TM}}$ Cold Room and Ambient Room. The initial temperature in the Coolbot ${ }^{\mathrm{TM}}$ cold room $16.9^{\circ} \mathrm{C}$ was preset $(10 \pm 2)^{\circ} \mathrm{C}$, which is the recommended cold storage temperature for mango fruits. The preset temperature was attained within an hour and remained stable/ constant during the 24-hour observation period. In the ambient room, the temperatures fluctuated between $24.9^{\circ} \mathrm{C}$ and $32.8^{\circ} \mathrm{C}$. The percentage relative humidity in the Coolbot $^{\mathrm{TM}}$ cold room and ambient room ranged between $80.6 \%$ $92.6 \%$ and $40.4 \%-71.5 \%$, respectively (Figure 1 ).

3.2. Fruit Pulp Temperature. The average internal pulp temperatures were $16.4^{\circ} \mathrm{C}$ and $31.4^{\circ} \mathrm{C}$ for fruits harvested during the cool morning hours versus hot afternoon, respectively. Upon arrival at the centre, pulp temperature of the fruits harvested in the morning averaged $27.5^{\circ} \mathrm{C}$ while that for fruits harvested at midday averaged $33.4^{\circ} \mathrm{C}$. After precooling, the pulp temperatures stabilized at $22.2^{\circ} \mathrm{C}$, $22.03^{\circ} \mathrm{C}, 22.1^{\circ} \mathrm{C}$, and $22.07^{\circ} \mathrm{C}$ for 'Apple', 'Ngowe', 'Kent', and 'Tommy Atkins' varieties, respectively, after 6 hours. There was a significant difference $(P>0.05)$ in pulp temperature for fruits under proper cold chain practices and those under farmer practices (no cold chain). However, there was no significant difference $(P>0.05)$ between pulp temperatures of the different mango varieties used in the study (Table 1).

3.3. Physiological Weight Loss (PWL). Physiological weight loss was recorded to be high in fruits under farmer practice. There was a significant difference $(P>0.05)$ in percentage cumulative weight loss between fruits under proper cold chain practices and farmer practices. At the end of storage (days 30-33), fruits under proper cold chain practices recorded \%PWL of $11.59 \%, 11.15 \%, 12.72 \%$, and $7.79 \%$ for Apple, Ngowe, Kent, and Tommy Atkins varieties, respectively. The fruits under farmer practices recorded significantly high PWL at the end of storage (days 12-15) averaging

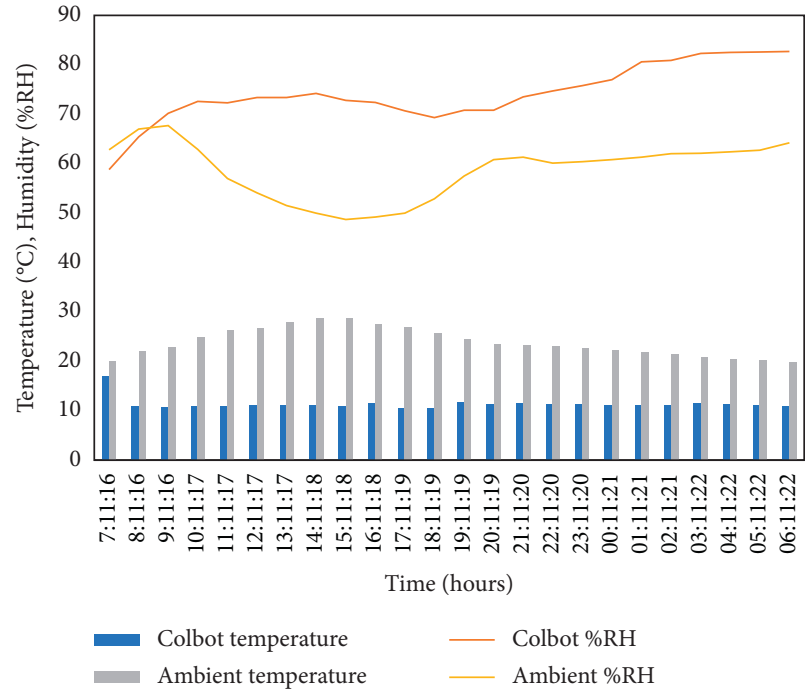

FIgURE 1: Differences in temperature $\left({ }^{\circ} \mathrm{C}\right)$ and relative humidity (\%) in the Coolbot ${ }^{\mathrm{TM}}$ cold room and ambient room during the first 24 hours of storage.

$14.96 \%, 13.46 \%, 17.71 \%$, and $12.96 \%$ for 'Apple', 'Ngowe', 'Kent', and 'Tommy Atkins' varieties, respectively (Table 2).

3.4. Peel and Flesh Colour. The peel colour of the fruits gradually changed from green to yellow as the fruits ripened while the flesh colour gradually changed from whitishyellow to full yellow. Hue angles for fruits under farmer practices steadily decreased as the fruits ripened faster as compared to fruits under proper cold chain practices. Peel colour of fruits decreased from initial hue angle value of $110.33^{\circ}, 130.72^{\circ}, 112.28^{\circ}$, and $111.12^{\circ}$ for 'Apple', 'Kent', 'Ngowe', and 'Tommy Atkins' varieties, respectively, to $73.89^{\circ}, 101.29^{\circ}, 77.34^{\circ}$, and $85.11^{\circ}$ at the end of storage for fruits under proper cold chain management as compared to fruits under poor cold chain management that recorded $61.85^{\circ}, 102.37^{\circ}, 55.8^{\circ}$, and $52.30^{\circ}$, respectively, at the end of storage (Table 3).

Similarly, flesh colour also decreased from initial hue angle value of $87.19^{\circ}, 89.41^{\circ}, 91.22^{\circ}$, and $89.12^{\circ}$ for 'Apple', 'Kent', 'Ngowe', and 'Tommy Atkins' varieties, respectively, to $66.87^{\circ}, 62.19^{\circ}, 73.58^{\circ}$, and $64.20^{\circ}$ at the end of storage for fruits under proper cold chain management. On the other hand, hues of fruits under poor cold chain management decreased to $63.80^{\circ}, 66.52^{\circ}, 66.0^{\circ}$, and $71.95^{\circ}$, respectively, at the end of storage, approximately 18 days earlier compared to fruits under proper cold chain practice (Table 4).

3.5. Peel and Flesh Firmness. Peel and flesh firmness decreased gradually as the fruits ripened, irrespective of the treatment and variety. Peel firmness of fruits under poor cold chain practices decreased from the initial $110.2 \mathrm{~N}$, $153.1 \mathrm{~N}, 118.5 \mathrm{~N}$, and $115.1 \mathrm{~N}$ to $22.7 \mathrm{~N}, 18.9 \mathrm{~N}, 30.1 \mathrm{~N}$, and $29.6 \mathrm{~N}$ for 'Apple', 'Ngowe', 'Kent', and 'Tommy Atkins' varieties, respectively, at the end of the storage. Fruit under proper cold chain practices decreased to $7.7 \mathrm{~N}, 6.7 \mathrm{~N}, 15.9 \mathrm{~N}$, 
TABle 1: Differences in pulp temperature $\left({ }^{\circ} \mathrm{C}\right)$ of four mango varieties as affected by cold chain management practices.

\begin{tabular}{|c|c|c|c|c|c|c|c|c|c|c|c|c|c|c|c|}
\hline \multirow{2}{*}{ Variety } & \multirow{2}{*}{ Treatment } & \multicolumn{13}{|c|}{ Days in storage } & \multirow{2}{*}{ Means } \\
\hline & & T0 & $\mathrm{T} 1$ & 3 & 6 & 9 & 12 & 15 & 18 & 21 & 24 & 27 & 30 & 33 & \\
\hline \multirow{2}{*}{ Apple } & Cold chain & $16.3^{\mathrm{b}}$ & $27.4^{\mathrm{c}}$ & $10.9^{\mathrm{a}}$ & $10.6^{\mathrm{b}}$ & $11.8^{\mathrm{a}}$ & $11.5^{\mathrm{a}}$ & $11.5^{\mathrm{b}}$ & $11.2^{\mathrm{a}}$ & $11.4^{\mathrm{a}}$ & $11.5^{\mathrm{ab}}$ & $11.9^{\mathrm{ab}}$ & $12.6^{\mathrm{b}}$ & & 13.2 \\
\hline & No cold chain & $31.6^{\mathrm{a}}$ & $33.5^{\mathrm{a}}$ & $23.5^{\mathrm{b}}$ & $24.2^{\mathrm{d}}$ & $24.8^{\mathrm{d}}$ & $22.3^{\mathrm{c}}$ & & & & & & & & 26.7 \\
\hline \multirow{2}{*}{ Kent } & Cold chain & $16.5^{\mathrm{b}}$ & $27.8^{\mathrm{b}}$ & $10.8^{\mathrm{a}}$ & $10.5^{\mathrm{b}}$ & $12^{\mathrm{a}}$ & $11.4^{\mathrm{a}}$ & $11.5^{\mathrm{b}}$ & $11.3^{\mathrm{a}}$ & $11.4^{\mathrm{a}}$ & $11.7^{\mathrm{bc}}$ & $12.1^{\mathrm{b}}$ & $12.5^{\mathrm{ab}}$ & 12.8 & 13.3 \\
\hline & No cold & $31.5^{\mathrm{a}}$ & $33^{\mathrm{a}}$ & $23.5^{\mathrm{b}}$ & $22.9^{\mathrm{bc}}$ & $23.6^{\mathrm{b}}$ & $22.2^{\mathrm{C}}$ & $20.7^{\mathrm{e}}$ & & & & & & & 25.3 \\
\hline \multirow{2}{*}{ Ngowe } & Cold chain & $16.3^{\mathrm{b}}$ & $27.5^{\mathrm{c}}$ & $11^{\mathrm{a}}$ & $11.2^{\mathrm{c}}$ & $12^{\mathrm{a}}$ & $11.5^{\mathrm{a}}$ & $10.6^{\mathrm{a}}$ & $11.1^{\mathrm{a}}$ & $11.8^{\mathrm{a}}$ & $11.9^{c}$ & $11.7^{\mathrm{a}}$ & $12.4^{\mathrm{a}}$ & & 13.3 \\
\hline & No cold chain & $31.6^{\mathrm{a}}$ & $33^{\mathrm{a}}$ & $23.5^{\mathrm{b}}$ & $24.4^{\mathrm{de}}$ & $24.3^{\mathrm{c}}$ & $22.8^{\mathrm{d}}$ & & & & & & & & 26.6 \\
\hline \multirow{2}{*}{ Tommy Atkins } & Cold chain & $16.3^{\mathrm{b}}$ & $27.3^{\mathrm{c}}$ & $11^{\mathrm{a}}$ & $9.9^{\mathrm{a}}$ & $11.7^{\mathrm{a}}$ & $11.2^{\mathrm{a}}$ & $11.3^{\mathrm{b}}$ & $11.3^{\mathrm{a}}$ & $11.8^{\mathrm{a}}$ & $11.3^{\mathrm{a}}$ & $11.9^{\mathrm{ab}}$ & $12.5^{\mathrm{ab}}$ & & 13.1 \\
\hline & No cold chain & $31^{\mathrm{a}}$ & $34^{\mathrm{a}}$ & $23.6^{\mathrm{b}}$ & $23.7^{\mathrm{e}}$ & $24.1^{\mathrm{c}}$ & $25.8^{\mathrm{b}}$ & & & & & & & & 27.0 \\
\hline \multirow{2}{*}{\multicolumn{2}{|c|}{ Treat $x$ variety (LSD 0.05$) \% C V$}} & 0.66 & 0.66 & 0.48 & 0.46 & 0.45 & 0.37 & 0.4 & $\mathbf{0 . 4}$ & 0. & 0.27 & 0. & 0.19 & 0. & \\
\hline & & 1.5 & 1.2 & 1.6 & 1.8 & 1.4 & 1.3 & 1.9 & 1.5 & 2.7 & 1.2 & 1.8 & 0.8 & 0.4 & \\
\hline
\end{tabular}

T0: pulp temperature immediately after harvest in the field; T1: pulp temperature upon arrival at the aggregation centre. Means within each column followed by different letters differ significantly at $P>0.05$.

TABLE 2: Changes in \% cumulative weight loss of four mango varieties as affected by cold chain management practices.

\begin{tabular}{|c|c|c|c|c|c|c|c|c|c|c|c|c|c|c|}
\hline \multirow{2}{*}{ Variety } & \multirow{2}{*}{ Treatment } & \multicolumn{12}{|c|}{ Days in storage } & \multirow{2}{*}{ Means } \\
\hline & & 0 & 3 & 6 & 9 & 12 & 15 & 18 & 21 & 24 & 27 & 30 & 33 & \\
\hline \multirow{2}{*}{ Apple } & Cold chain & 0.00 & $1.66^{\mathrm{a}}$ & $2.57^{\mathrm{a}}$ & $3.19^{\mathrm{a}}$ & $4.51^{\mathrm{a}}$ & $5.00^{\mathrm{a}}$ & $7.70^{\mathrm{b}}$ & $8.47^{\mathrm{b}}$ & $9.58^{\mathrm{b}}$ & $10.62^{\mathrm{b}}$ & $11.59^{\mathrm{b}}$ & & 5.90 \\
\hline & No cold chain & 0.00 & $4.09^{\mathrm{b}}$ & $8.35^{\mathrm{c}}$ & $11.30^{\mathrm{c}}$ & $14.96^{\mathrm{b}}$ & & & & & & & & 7.74 \\
\hline \multirow{2}{*}{ Kent } & Cold chain & 0.00 & $1.52^{\mathrm{a}}$ & $3.10^{\mathrm{a}}$ & $3.79^{\mathrm{a}}$ & $4.57^{\mathrm{a}}$ & $5.63^{\mathrm{a}}$ & $7.26^{\mathrm{ab}}$ & $7.99^{\mathrm{b}}$ & $9.62^{\mathrm{b}}$ & $10.57^{\mathrm{b}}$ & $11.51^{\mathrm{b}}$ & 12.72 & 6.52 \\
\hline & No cold chain & 0.00 & $3.45^{\mathrm{b}}$ & $7.68^{\mathrm{bc}}$ & $10.47^{\mathrm{bc}}$ & $13.98^{\mathrm{b}}$ & $17.71^{\mathrm{c}}$ & & & & & & & 8.88 \\
\hline \multirow{2}{*}{ Ngowe } & Cold chain & 0.00 & $1.75^{\mathrm{a}}$ & $2.65^{\mathrm{a}}$ & $3.54^{\mathrm{a}}$ & $4.77^{\mathrm{a}}$ & $5.58^{\mathrm{a}}$ & $6.99^{\mathrm{ab}}$ & $7.99^{\mathrm{b}}$ & $9.22^{\mathrm{b}}$ & $10.16^{\mathrm{b}}$ & $11.15^{\mathrm{b}}$ & & 5.80 \\
\hline & No cold chain & 0.00 & $3.75^{\mathrm{b}}$ & $8.01^{\mathrm{c}}$ & $10.85^{b c}$ & $13.46^{\mathrm{b}}$ & & & & & & & & 7.21 \\
\hline \multirow{2}{*}{ Tommy Atkins } & Cold chain & 0.00 & $1.76^{\mathrm{a}}$ & $2.19^{\mathrm{a}}$ & $2.58^{\mathrm{a}}$ & $3.07^{\mathrm{a}}$ & $3.90^{\mathrm{a}}$ & $5.10^{\mathrm{a}}$ & $5.43^{\mathrm{a}}$ & $6.53^{\mathrm{a}}$ & $7.19^{\mathrm{a}}$ & $7.79^{\mathrm{a}}$ & & 4.14 \\
\hline & No cold chain & 0.00 & $3.62^{\mathrm{b}}$ & $6.78^{\mathrm{b}}$ & $9.40^{\mathrm{b}}$ & $12.95^{\mathrm{b}}$ & & & & & & & & 6.55 \\
\hline \multirow{2}{*}{\multicolumn{2}{|c|}{ Treat $x$ variety (LSD 0.05$) \mathrm{CV}$}} & & 0.97 & 1.38 & 1.79 & 2.31 & 2 & 2.2 & 1.52 & 1.89 & 1. & 1.8 & 3.61 & \\
\hline & & (\%) & 20.8 & 15.3 & 14.9 & 14.7 & 13.1 & 11.4 & 10.8 & 13.9 & 8.8 & 9.1 & 8.1 & \\
\hline
\end{tabular}

Means within each column followed by different letters differ significantly at $P>0.05$.

and 9N for 'Apple', 'Ngowe', 'Kent', and 'Tommy Atkins' varieties, respectively, at the end storage, 18 days earlier compared to fruits under proper cold chain management (Table 5).

Similar trends were recorded in flesh firmness of fruits under the study. Flesh firmness of fruits under poor cold chain practices decreased from initial $36.6 \mathrm{~N}, 45.9 \mathrm{~N}, 66.5 \mathrm{~N}$, and $46.8 \mathrm{~N}$ to $3.1 \mathrm{~N}, 2.4 \mathrm{~N}, 3.2 \mathrm{~N}$, and $3.1 \mathrm{~N}$ for 'Apple', 'Ngowe', 'Kent', and 'Tommy Atkins' varieties, respectively, at the end of storage while fruits under proper cold chain practices decreased to $2.3 \mathrm{~N}, 1.5 \mathrm{~N}, 3.9 \mathrm{~N}$, and $2.9 \mathrm{~N}$ for 'Apple', 'Ngowe', 'Kent', and 'Tommy Atkins' varieties, respectively, on the final day of storage (Table 6).

3.6. Total Soluble Solids (TSS). Total soluble solids increased as the fruits ripened irrespective of the treatment and variety. The TSS for fruits under poor cold chain practices increased from the initial $8.47^{\circ}$ Brix, $6.7^{\circ}$ Brix, $5.63^{\circ}$ Brix, and $8.7^{\circ}$ Brix to $22.63^{\circ}$ Brix, $20.23^{\circ}$ Brix, $13.9^{\circ}$ Brix, and $18.23^{\circ}$ Brix for Apple, Ngowe, Kent, and Tommy Atkins varieties, respectively, at the end of storage while for fruits under proper cold chain practices they increased to $19.43^{\circ} \mathrm{Brix}, 20.2^{\circ} \mathrm{Brix}, 14.03^{\circ} \mathrm{Brix}$, and $15.90^{\circ}$ Brix for 'Apple', 'Ngowe', 'Kent', and 'Tommy Atkins' varieties, respectively, at the end of storage (Table 7).
3.7. Overall Shelf Life. The overall shelf life was determined by the number of days to a predetermined end-stage for the fruits based on firmness and visual appearance at which the fruit was saleable. Fruits under poor cold chain practices had a shorter shelf life of 12 days for 'Apple', 'Ngowe', and 'Tommy Atkins' varieties and 15 days for 'Kent' variety. On the other hand, fruits under proper cold chain practices had a longer shelf life of 30 days for 'Apple', 'Ngowe', and 'Tommy Atkins' varieties and 33 days for 'Kent variety' (Figure 2).

\section{Discussion}

Temperature management to maintain a proper cold chain for fresh horticultural produce is key to preserving quality and reducing postharvest losses in perishable commodities [21]. For smallholder horticultural farmers with limited resources, simple harvest practices coupled with low-cost cold storage can be used to achieve a desirable cold chain. In the present study, the effectiveness of these practices and technologies was evaluated in mango fruits. The study evaluated proper cold chain practices or poor cold chain practices (farmer practices) in four mango varieties, namely, 'Apple', 'Ngowe', 'Kent', and 'Tommy Atkins'. The effect of 


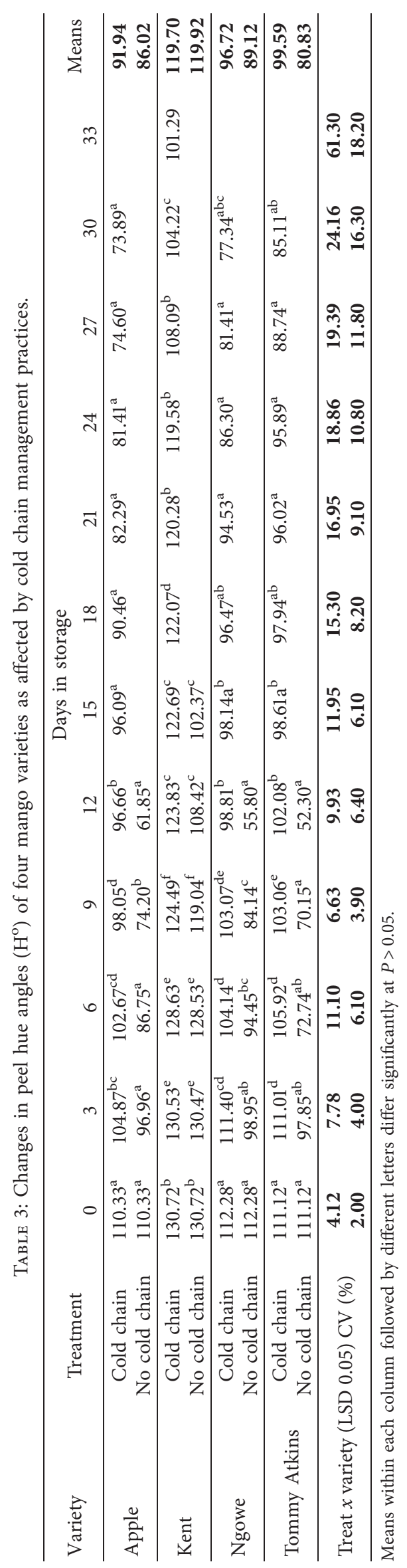




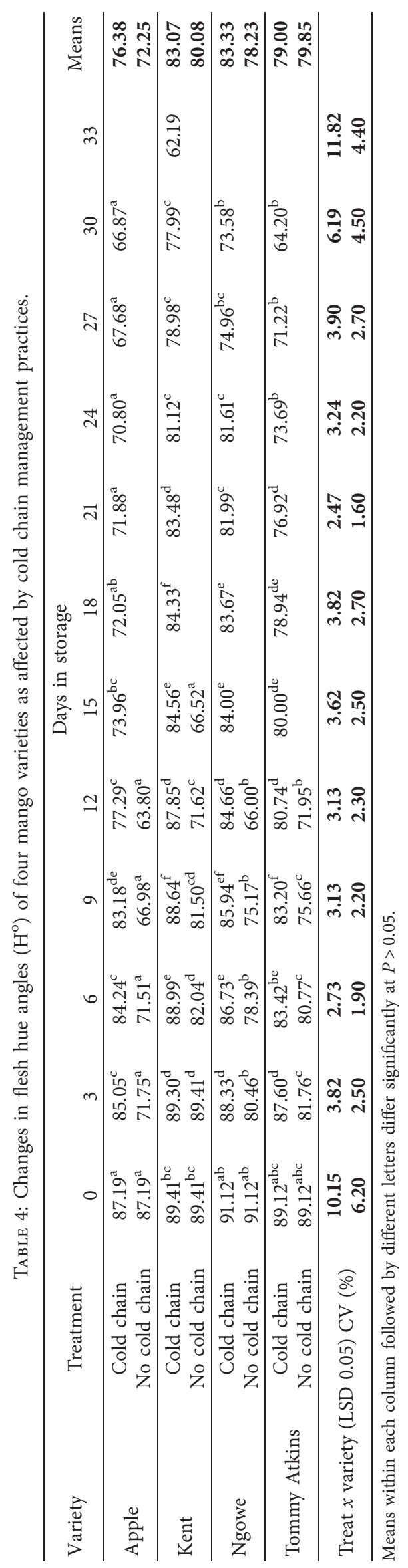




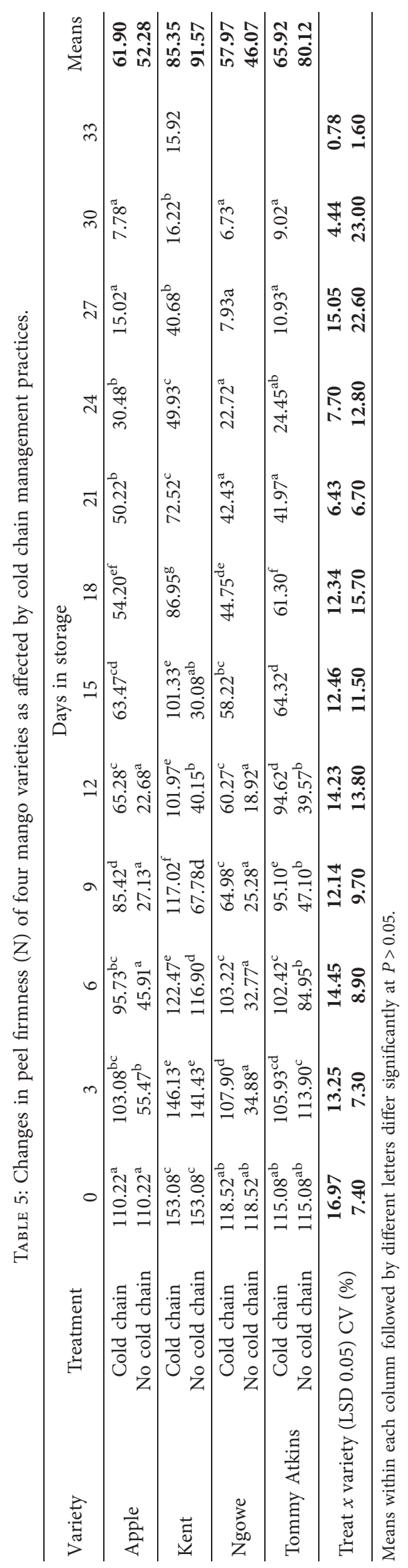


TABLE 6: Changes in flesh firmness $(\mathrm{N})$ of four mango varieties as affected by cold chain management practices.

\begin{tabular}{|c|c|c|c|c|c|c|c|c|c|c|c|c|c|c|}
\hline \multirow{2}{*}{ Variety } & \multirow{2}{*}{ Treatment } & \multicolumn{12}{|c|}{ Days in storage } & \multirow{2}{*}{ Means } \\
\hline & & 0 & 3 & 6 & 9 & 12 & 15 & 18 & 21 & 24 & 27 & 30 & 33 & \\
\hline \multirow[b]{2}{*}{ Apple } & Cold & $36.55^{\mathrm{a}}$ & $32.50^{\mathrm{b}}$ & $31.90^{\mathrm{b}}$ & $25.13^{\mathrm{c}}$ & $22.85^{\mathrm{c}}$ & $17.13^{\mathrm{bc}}$ & $14.58^{\mathrm{abc}}$ & $6.73^{\mathrm{a}}$ & $5.96^{\mathrm{a}}$ & $4.60^{\mathrm{ab}}$ & $2.27^{\mathrm{a}}$ & & 18.20 \\
\hline & Jo & $36.55^{\mathrm{a}}$ & $10.12^{\mathrm{a}}$ & $6.92^{\mathrm{a}}$ & $3.62^{\mathrm{a}}$ & $3.13^{\mathrm{a}}$ & & & & & & & & 12.07 \\
\hline \multirow{2}{*}{ Kent } & Cold chain & $66.47^{\mathrm{b}}$ & $49.57^{\mathrm{d}}$ & $42.57^{\mathrm{c}}$ & $31.07^{\mathrm{d}}$ & $20.48^{\mathrm{d}}$ & $20.43^{\mathrm{d}}$ & $17.50^{c}$ & $10.92^{\mathrm{a}}$ & $9.05^{\mathrm{b}}$ & $6.13^{b}$ & $5.85^{\mathrm{b}}$ & 3.95 & 23.67 \\
\hline & No cold & $66.47^{\mathrm{b}}$ & $41.78^{\mathrm{cd}}$ & $11.22^{\mathrm{a}}$ & $8.05^{\mathrm{ab}}$ & $6.80^{\mathrm{ab}}$ & $3.20^{\mathrm{ab}}$ & & & & & & & 22.92 \\
\hline \multirow{2}{*}{ Ngowe } & Cold & $45.98^{\mathrm{a}}$ & $36.35^{b c}$ & $32.67^{\mathrm{b}}$ & $19.13^{b c}$ & $11.88^{\mathrm{b}}$ & $9.52^{\mathrm{abc}}$ & $8.82^{\mathrm{abc}}$ & $7.57^{\mathrm{a}}$ & $6.02^{\mathrm{a}}$ & $2.78^{\mathrm{a}}$ & $1.49^{\mathrm{a}}$ & & 16.56 \\
\hline & No $\mathrm{co}$ & $45.98^{\mathrm{a}}$ & $6.45^{\mathrm{a}}$ & $4.82^{\mathrm{a}}$ & $4.68^{\mathrm{a}}$ & $2.42^{\mathrm{a}}$ & & & & & & & & 12.87 \\
\hline \multirow{2}{*}{ Tommy Atkins } & Cold chain & $46.75^{\mathrm{a}}$ & $40.82^{\mathrm{bc}}$ & $35.63^{\mathrm{b}}$ & $33.02^{c}$ & $25.58^{\mathrm{c}}$ & $18.60^{\mathrm{C}}$ & $15.25^{\mathrm{bc}}$ & $11.27^{\mathrm{a}}$ & $6.53^{\mathrm{a}}$ & $3.59^{\mathrm{a}}$ & $2.95^{\mathrm{a}}$ & & 21.82 \\
\hline & No cold chain & $46.75^{\mathrm{a}}$ & $38.22^{\mathrm{b}}$ & $7.05^{\mathrm{a}}$ & $6.48^{\mathrm{a}}$ & $3.15^{\mathrm{ab}}$ & & & & & & & & 20.33 \\
\hline \multirow{2}{*}{\multicolumn{2}{|c|}{$\begin{array}{c}\text { Treat } x \text { variety (LSD 0.05) CV } \\
(\%)\end{array}$}} & 12.78 & 13.47 & 9.87 & 11.58 & 8.38 & & 10.8 & 9. & 1 & 8. & 2.16 & 4.1 & \\
\hline & & 15 & 22 & 25.3 & 28.1 & 23.2 & 21.6 & 27.6 & 21.3 & 12.6 & 22.5 & 23.3 & 28.5 & \\
\hline
\end{tabular}

Means within each column followed by different letters differ significantly at $P>0.05$.

TABLE 7: Changes in total soluble solids (TSS) of four mango varieties as affected by cold chain management practices.

\begin{tabular}{|c|c|c|c|c|c|c|c|c|c|c|c|c|c|c|}
\hline \multirow{2}{*}{ Variety } & \multirow{2}{*}{ Treatment } & \multicolumn{12}{|c|}{ Days in storage } & \multirow[t]{2}{*}{ Means } \\
\hline & & 0 & 3 & 6 & 9 & 12 & 15 & 18 & 21 & 24 & 27 & 30 & 33 & \\
\hline \multirow[b]{2}{*}{ Apple } & Core & $8.47^{c}$ & $8.60^{\mathrm{bc}}$ & $10.03^{\mathrm{b}}$ & $10.10^{\mathrm{b}}$ & $10.20^{\mathrm{b}}$ & $12.13^{\mathrm{b}}$ & $13.13^{\mathrm{bcd}}$ & $14.20^{\mathrm{bc}}$ & $15.00^{\mathrm{b}}$ & $15.10^{\mathrm{b}}$ & $19.43^{\mathrm{b}}$ & & 12.40 \\
\hline & No cold chain & $8.47^{\mathrm{c}}$ & $9.07^{\mathrm{bc}}$ & $12.93^{\mathrm{c}}$ & $13.37^{\mathrm{d}}$ & $22.63^{\mathrm{g}}$ & & & & & & & & 13.29 \\
\hline \multirow{2}{*}{ Kent } & Cold chain & $5.63^{\mathrm{a}}$ & $6.63^{\mathrm{a}}$ & $6.67^{\mathrm{a}}$ & $6.80^{\mathrm{a}}$ & $8.97^{\mathrm{a}}$ & $9.20^{\mathrm{a}}$ & $10.43^{\mathrm{a}}$ & $11.17^{\mathrm{a}}$ & $11.53^{\mathrm{a}}$ & $13.00^{\mathrm{a}}$ & $13.33^{\mathrm{a}}$ & 14.03 & 9.78 \\
\hline & No cold chain & $5.63^{\mathrm{a}}$ & $7.10^{\mathrm{bc}}$ & $9.40^{\mathrm{b}}$ & $11.50^{\mathrm{bc}}$ & $12.80^{\mathrm{C}}$ & $13.90^{\mathrm{cd}}$ & & & & & & & 10.06 \\
\hline \multirow{2}{*}{ Ngowe } & Cold chain & $6.70^{\mathrm{b}}$ & $10.10^{\mathrm{c}}$ & $10.93^{\mathrm{b}}$ & $11.53^{\mathrm{c}}$ & $14.80^{\mathrm{d}}$ & $15.90^{\mathrm{e}}$ & $16.63^{\mathrm{de}}$ & $16.93^{c}$ & $17.83^{c}$ & $18.03^{\mathrm{c}}$ & $20.20^{\mathrm{b}}$ & & 14.51 \\
\hline & No cold chain & $6.70^{\mathrm{b}}$ & $13.67^{\mathrm{e}}$ & $17.47^{\mathrm{d}}$ & $19.73^{\mathrm{e}}$ & $20.23^{f}$ & & & & & & & & 15.56 \\
\hline \multirow{2}{*}{ Tommy Atkins } & Cold c & $8.70^{c}$ & $9.00^{\mathrm{b}}$ & $9.33^{\mathrm{a}}$ & $9.73^{\mathrm{b}}$ & $10.40^{\mathrm{a}}$ & $11.33^{\mathrm{cd}}$ & $12.07^{\mathrm{ab}}$ & $13.17^{\mathrm{ab}}$ & $13.20^{\mathrm{a}}$ & $14.67^{\mathrm{b}}$ & $15.90^{\mathrm{a}}$ & & 11.59 \\
\hline & No cold chain & $8.70^{\mathrm{c}}$ & $11.97^{\mathrm{d}}$ & $12.23^{\mathrm{c}}$ & $15.20^{\mathrm{d}}$ & $18.23^{\mathrm{e}}$ & & & & & & & & 13.27 \\
\hline \multirow{2}{*}{\multicolumn{2}{|c|}{$\begin{array}{c}\text { Treat } x \text { variety (LSD } 0.05) \mathrm{CV} \\
(\%)\end{array}$}} & 0.85 & 1.34 & 1.53 & 1.66 & 1.13 & 1.07 & 2.93 & 3.00 & 1.59 & 1.65 & 3.18 & 2.68 & \\
\hline & & 6.70 & 8.00 & 8.30 & 7.60 & 4.50 & 4.50 & 11.90 & 12.00 & 5.90 & 5.60 & 9.80 & 5.40 & \\
\hline
\end{tabular}

Means within each column followed by different letters differ significantly at $P>0.05$.

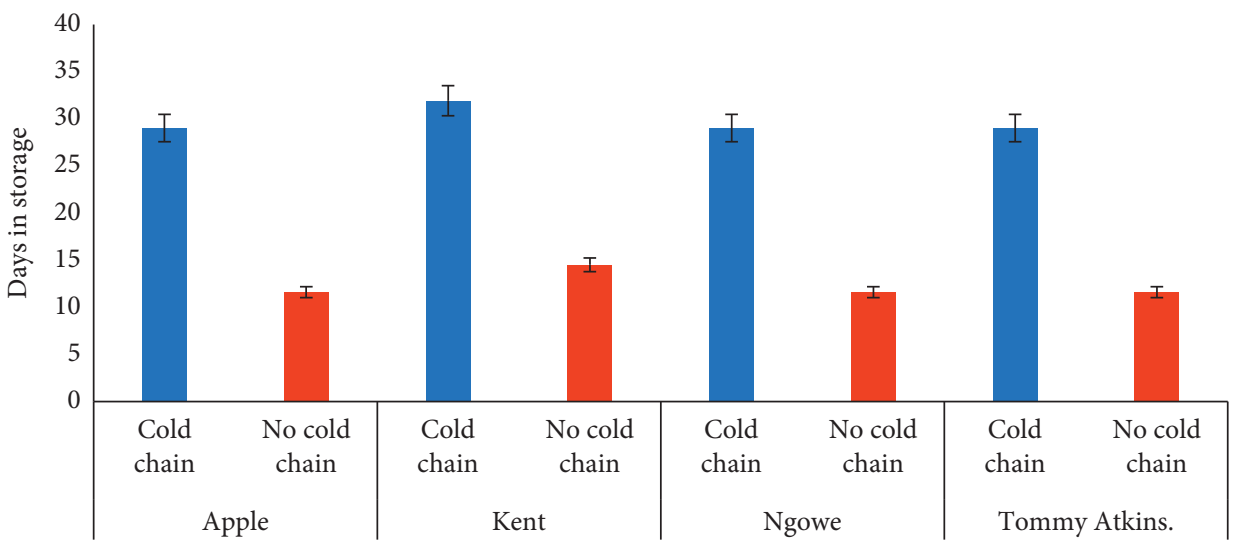

Figure 2: Overall shelf life of four mango varieties ('Apple', 'Kent', 'Ngowe', and 'Tommy Atkins') handled either under proper cold chain management or under poor cold chain management practices. Top bars represent SE of means $(P \leq 0.05)$.

the two cold chain options (proper and poor cold chain) on ripening related changes (physiological weight loss, hue angle, firmness, and total soluble solids) and the overall shelf life of the fruits was evaluated.

Harvest time greatly affected the pulp temperature with fruits harvested during hotter hours of the day recording high pulp temperatures due to high heat load. Horticultural produce accumulates heat during harvesting and postharvest handling, which reduces their storage quality [22]. High heat load is one of the major causes of deterioration in harvested commodities. Harvesting and handling the harvested produce under cool temperatures are critical for postharvest quality preservation [12]. Harvested produce should be precooled or cooled immediately after harvest. Fruits harvested during hot hours of the day should be precooled immediately to remove field heat and slow physiological 
processes [23]. Previous studies have shown that delayed cooling for just one hour can result in a one-day loss of shelf life [24]. Precooled fruits have reduced metabolic activities rate leading to quality preservation and shelf life extension [17]. Precooling can be done either by hydrocooling, vacuum cooling, or forced air cooling, depending on the commodity and cost-benefit associated with it [25]. For smallholder farmers, evaporative coolers can be used to precool fruits and vegetables prior to refrigerated transport and storage. Precooling also improves cold-resisting ability and minimizes chilling injury on fresh produce. A rapid removal of field heat by precooling before storage is critical for the efficient running of the cold storage facility. Evaporative coolers have been used to achieve cool temperatures necessary for precooling and short-term storage of harvested horticultural produce [26].

Proper cold chain management significantly reduced the rate of ripening-related changes, including physiological weight loss, peel and flesh colour, peel and flesh firmness, and increase in TSS, ultimately increasing the shelf life of mango fruits by an additional 18 days.

Although there was a gradual increase in physiological weight loss during storage irrespective of the treatment, the rate was slower under proper cold chain management. Physiological weight loss in harvested commodities results in shorter shelf life and loss of quality through wilting and shriveling [27]. The higher weight loss in fruits under poor cold chain management practices can be attributed to high temperatures and low humidity. The rate of physiological weight loss and shriveling is dependent on respiration and transpiration and is accelerated with high temperature and low humidity [28]. Under proper cold chain management practices, minimal water loss through transpiration and substrate breakdown during respiration resulted from low temperatures and high humidity. This condition creates a low vapour pressure deficit (VPD) for the fruits and the area around the fruit, leading to slowed water loss from the fruits to the surrounding air. Similar results of reduced water loss under low temperatures and high humidity have been reported in mango [17] and avocado [29].

Colour is an important indicator of ripeness and freshness among fruits. In the present study, peel and flesh color (measured as hue angle) gradually decreased as fruits ripened irrespective of the treatment (cold chain practice) and variety. The decrease in hue angles was steady in fruits subjected to poor cold chain management practices, hence shorter shelf life. The slower color change in fruits under proper cold chain management practices can be attributed to low temperatures leading to reduced metabolic activities. Low temperatures also slow down ethylene biosynthesis and processes triggered by ethylene in ripening fruits chlorophyll degradation by chlorophyll oxidase [30]. Artes et al. [31] also attribute the colour change to delay in the biosynthesis of anthocyanins and carotenoids resulting from the reduced metabolic processes due to low temperatures in proper cold chain practices. The inhibition of metabolic and enzymatic reactions responsible for ripening due to low temperature has previously been reported in mango [32] and indigenous fruits such as Ber [33].
Peel and flesh firmness decreased as fruits ripened irrespective of the treatment and variety. At the end-stage for fruits under poor cold chain practices, firmness had decreased to less than $50 \%$ while those under proper cold chain practices remained firmer till day 30 ('Apple', 'Ngowe', and 'Tommy Atkins') and day 33 ('Kent') varieties, respectively. The decrease in fruit firmness is attributed to activities of enzymes involved in cell metabolism, depolymerization of cell wall pectin [34]. The enzymes include pectin methylesterase (PME), polygalacturonase (PG), endo-B-1,4-glucanase (EGase), and pectate lyase [35]. The high firmness retention in fruits under proper cold chain management practices results from low temperatures that could have slowed down the activities of the enzymes involved in ripening. Reduced transpiration in fruits under proper cold chain due to high humidity and low temperature could also explain the high firmness in fruits stored under such conditions since they remained turgid due to minimal moisture loss [36]. The finding of the present study is in line with previous studies on the effect of low temperatures on the firmness of mango [17] and avocado [29].

Total soluble solids increased gradually in all the treatments. An increase in TSS is attributed to starch breakdown into simple sugar as ripening progress [37]. Fruits under poor cold chain practices had a faster increase in TSS and over a shorter period of time as compared to those under proper cold chain practices. For example, 'Apple' mango under poor cold chain practices had TSS of $22.63^{\circ}$ Brix on day 12 , compared to $19.43^{\circ}$ Brix on day 30 under proper cold chain management. A high increase in TSS of fruits under warmer conditions in poor cold chain management could be attributed to a high respiration rate and other metabolic activities. The increase can also be attributed to higher activity on enzymes (sucrose synthase, invertase, and amylase) involved in starch breakdown [38]. TSS is varietal-dependent, hence the observed significant difference among the four mango varieties used in the present study [36]. The finding of this present study concurs with similar studies previously done on mango [17] and grapefruit [39].

Overall, proper cold chain practices extended the shelf life of mango fruits (all varieties) which remained saleable until day 30 ('Apple', 'Ngowe', and 'Tommy Atkins') and day 33 ('Kent'). This was 18 more than fruits under poor cold chain practices. The shelf life of fruits under proper cold chain practices was enhanced by a synergistic effect of proper time of harvest, precooling, storage at low temperature, and high humidity. This in turn reduced the rate of ripening and deterioration of the fruits during storage.

\section{Conclusion}

Application of simple harvest and postharvest handling practices coupled with simple low-cost cold storage technologies can achieve desirable cold chain in perishable commodities such as mango. Proper cold chain practices significantly maintained lower internal pulp temperatures (averaging $11^{\circ} \mathrm{C}$ ) when compared to poor cold chain practices (averaging $25^{\circ} \mathrm{C}$ ), thus lowering metabolic reactions that still take place in harvested fruits that result in 
faster ripening and deterioration. This can in turn extend the shelf life of the perishable commodities and significantly increase their marketing period while reducing postharvest losses. Overall, proper cold chain management preserved quality (water loss, firmness, colour, and TSS) and extended shelf life of harvested mango fruits by 18 days more when compared to handling practices common among smallholder farmers. These practices and technologies can be adopted by smallholder farmers especially those doing aggregation of fruits for later selling and/or processing, thus enabling high bargaining power that results in better returns.

\section{Data Availability}

The data used in this manuscript are available upon request to the first author (emmanuelamwoka@gmail.com) and the corresponding author(ambuko@yahoo.com).

\section{Conflicts of Interest}

The authors declare that there are no conflicts of interest.

\section{Acknowledgments}

The authors are grateful to the Karurumo horticultural farmers' self-help group for allowing them to use their aggregation centre during this study. The funding of this research was provided by the Rockefeller Foundation under Yieldwise Initiative (Grant number: 2016 YWS 328) awarded to Prof. Jane Ambuko of the University of Nairobi.

\section{References}

[1] Horticultural Crops Directorate (HCD), Validated Report 2016-2017, Horticultural Crops Directorate (HCD), Kenya, 2017.

[2] FAO, "Food losses and waste in the context of sustainable food systems. High Level Panel of Experts (HLPE)," Report 8, FAO, Rome, Italy, 2014.

[3] M. Reid, J. Thompson, and C. Chih-Ham, Small-scale Coolrooms and Cool Transport for Limited Resource Farmers, 2010.

[4] L. Kitinoja, Use of Cold Chains for Reducing Food Losses in Developing Countries, AMAIZZ, no. 13, , pp. 1-16, Tel Aviv, Israel, 2013.

[5] A. A. Kader, "Postharvest technology of horticultural crops," Agriculture and Natural Resources, vol. 3311, pp. 533-535, 2002.

[6] R. Lufu, A. Ambaw, and U. L. Opara, "Water loss of fresh fruit: influencing pre-harvest, harvest and postharvest factors," Scientia Horticulturae, vol. 272, 2020.

[7] S. Tyagi, S. Sahay, M. Imran, K. Rashmi, and S. Mahesh, "Preharvest factors influencing the postharvest quality of fruits: a review," Current Journal of Applied Science and Technology, vol. 23, no. 4, pp. 1-12, 2017.

[8] H. Deirdre, Water Relations in Harvested Fresh Produce, University of California, Davis, Davis, CA, USA, 2015.

[9] V. Kiaya, "Post-harvest losses and strategies to," The Journal of Agricultural Science, vol. 149, no. 3-4, pp. 49-57, 2014.

[10] O. gumo, C. N. Kunyanga, J. W. Kimenju, and M. W. Okoth, "Effects of harvest time and duration before cooling on the post-harvest quality and shelf-life stability of French bean
(Phaseolus Vulgaris L.)," Journal of Nutrition \& Food Sciences, vol. 8, no. 5, 2018.

[11] Z. S. Ilić, L. Milenković, L. Šunić, and M. Manojlović, "Color shade nets improve vegetables quality at harvest and maintain quality during storage," Contemporary Agriculture, vol. 67, no. 1, pp. 9-19, 2018.

[12] I. Kojo, A. Harrison, K. Ernest Kodzo, and H. Ofori, "Preharvest and postharvest factors affecting the quality and shelf life of harvested tomatoes: a mini review," International Journal of Agronomy, vol. 2015, Article ID 478041, 6 pages, 2015.

[13] E. Pressman, M. M. Peet, and D. Mason Pharr, "The effect of heat stress on tomato pollen characteristics is associated with changes in carbohydrate concentration in the developing anthers," Annals of Botany, vol. 90, no. 5, pp. 631-636, 2002.

[14] Z. Yang, Z. Ma, C. Zhao, and Y. Chen, "Study on forced-air pre-cooling of longan," in Proceedings of the 2007 ASAE Annual Meeting American Society of Agricultural and Biological Engineers, Minneapolis, MI, USA, June 2007.

[15] K. Cherono, M. Sibomana, and S. W. Tilahun, "Effect of infield handling conditions and time to pre-cooling on the shelf-life and quality of tomatoes," Brazilian Journal of Food Technology, vol. 21, 2018.

[16] N. Dubey, Technologies for Horticultural Development: CoolBot Provides Inexpensive, Effective Cooling, University of California, Davis, Davis, CA, USA, 2011, http://hortcrsp. ucdavis.edu/main/media/technologies_CoolBot.pdf.

[17] J. Ambuko and E. Karithi, "Postharvest shelf life of mango fruits stored in a CoolbotTM cold room," Acta Horticulturae, vol. 1225, 2018.

[18] A. lal Basediya, D. V. K. Samuel, and V. Beera, "Evaporative cooling system for storage of fruits and vegetables - a review," Journal of Food Science and Technology, vol. 50, no. 3, pp. 429-442, 2013.

[19] A. Jane, F. Wanjiru, G. N. Chemining'wa, W. O. Owino, and E. Mwachoni, "Preservation of postharvest quality of leafy amaranth (Amaranthus spp) vegetables using evaporative cooling," Journal of Food Quality, vol. 2017, Article ID 5303156, 6 pages, 2017.

[20] F. Manyoo and J. Ambuko, "Effectiveness of evaporative cooling technologies to preserve the postharvest quality of tomato," International Journal of Agronomy and Agricultural Research, vol. 13, 2018.

[21] M. M. Aung and Y. S. Chang, "Temperature management for the quality assurance of a perishable food supply chain," Food Control, vol. 40, pp. 198-207, 2014.

[22] J. H. Venema, P. Linger, A. W. Heusden, P. R. Hasselt, and W. Brüggemann, "The inheritance of chilling tolerance in tomato (lycopersiconspp.)," Plant Biology, vol. 7, no. 2, pp. 118-130, 2005.

[23] C. T. Kathryn and W. R. James, Harvesting and Handling Peaches, University of Georgia, Athens, Georgia, 2004, http:// www.ent.uga.edu/peach/peachhbk/harvest/ harvestandhandle.pdf.

[24] G. I. Johnson and P. J. Hofman, "Postharvest technology and quarantine treatments," in The Mango: Botany, Production and Uses, R. E. Litz, Ed., p. 529605, second ed. edition, CABI, Wallingford, UK, 2009.

[25] B. J. Jobling, "Correct cool chain management is essential for all fruit and vegetables," Sydney Postharvest Laboratory, Sydney, Australia, 2001.

[26] B. G. Jahun, S. A. Abdulkadir, S. M. Musa, and H. Umar, "Assessment of evaporative cooling system for storage of 
vegetables," International Journal of Science and Research (IJSR), vol. 5, no. 1, pp. 1197-1203, 2016.

[27] H. A. Rathore, T. Masud, S. Sammi, and A. Hussain Soomro, "Effect of storage on physico-chemical composition and sensory properties of mango (mangifera indica L.) variety dosehari," Pakistan Journal of Nutrition, vol. 6, no. 2, pp. 143-148, 2007.

[28] E. Abiso and N. Atheesh, H. Addisalem, "Effect of storage methods and ripening stages on postharvest quality of tomato ( lycopersicom esculentum mill ) $\mathrm{cv}$. Chali effect of storage methods and ripening stages on postharvest tomato (Lycopersicom Esculentum L .) is botanically classified as a Fr." Annals Food Science and Technology, vol. 16, no. 1, pp. 127137, 2015.

[29] R. J. Blakey, J. P. Bower, and I. Bertling, "Importance of cold chain maintenance and storage temperature to avocado ripening and quality," Acta Horticulturae, vol. 911, no. 911, pp. 555-564, 2011.

[30] R. M. Beaudry, "Responses of horticultural commodities to low oxygen: limits to the expanded use of modified atmosphere packaging," HortTechnology, vol. 10, no. 3, pp. 491-500, 2000.

[31] F. Artés, P. A. Gómez, and F. Artés-Hernández, "Modified atmosphere packaging of fruits and vegetables," Critical Reviews in Food Science and Nutrition, vol. 28, pp. 1-13, 2006.

[32] O. Hafeez, "Impact of different packaging types and low temperature shipping durations on fruit quality and marketability of Pakistani mangoes," International Journal of Agriculture and Biology, vol. 14, no. 1, pp. 47-54, 2012.

[33] L. Tembo, "Storage temperature affects fruit quality attributes of ber (Ziziphus mauritiana lamk.) in Zimbabwe," African Journal of Biotechnology, vol. 7, no. 17, pp. 3092-3099, 2008.

[34] B. Jarimopas and U. Kitthawee, "Firmness properties of mangoes," International Journal of Food Properties, vol. 10, no. 4, pp. 899-909, 2007.

[35] H. Lazan, M. K. Selamat, and Z. M. Ali, "beta-Galactosidase, polygalacturonase and pectinesterase in differential softening and cell wall modification during papaya fruit ripening," Physiologia Plantarum, vol. 95, no. 1, pp. 106-112, 1995.

[36] M. Tigist, T. S. Workneh, and K. Woldetsadik, "Effects of variety on the quality of tomato stored under ambient conditions," Journal of Food Science and Technology, vol. 50, no. 3, pp. 477-486, 2013.

[37] M. W. Siddiqui and R. S. Dhua, "Standardization of ethrel treatment for inducing ripening of mango var. Himsagar," in Proceedings of the International Conference on Horticulture, Nanjing, China, January 2009.

[38] S. Kumar, D. K. Das, A. K. Singh, and U. S. Prasad, "Sucrose metabolism during maturation and ripening of mango cultivars," Plant Physiology and Biochemistry, vol. 21, no. 1, pp. 27-32, 1994.

[39] O. Pailly, G. Tison, and A. Amouroux, "Harvest time and storage conditions of 'Star Ruby' grapefruit (Citrus paradisi Macf.) for short distance summer consumption," Postharvest Biology and Technology, vol. 34, no. 1, pp. 65-73, 2004. 